Universal Decimal Classification (UDC) 543:544

\title{
ASSESSMENT OF THE AIRBORNE PHTHALATE EXPOSURE ON LUNG FUNC- TION OF PRESCHOOL AND PRIMARY SCHOOL CHILDREN
}

\author{
T.S. Ulanova ${ }^{1,2}$, T.D. Karnazhitskaya ${ }^{1}$, E.O. Zavernenkova ${ }^{1}$ \\ ${ }^{1}$ FBSI "Federal Scientific Center for Medical and Preventive Health Risk Management Technologies", 82 Monas- \\ tyrskaya St., Perm, Russian Federation, 614045 \\ ${ }^{2}$ FBSEI HPE "Perm National Research Polytechnic University”, Komsomolsky Av. 29, Perm, Russian Federation, \\ 614990
}

The results of the studies of phthalates' content in the indoor and outdoor air on the territory of preschool and school educational institutions, the definition of phthalates metabolites in the urine and parameters of lung function of children attending these institutions are presented in the work. The HPLC/MS method detected the presence of 4 phthalates in 7 analyzed rooms and the air of pre-school and school facilities in the range $0.0002-0.00116 \mathrm{mg} / \mathrm{m}^{3}$ concentrations. The method of HPLC/MS/TFE metabolites detected the presence of phthalate (monometylphthalate, monobutylphthalate, monohexylilphthalate) in the urine of children in the concentration range of $0.00039-0.012 \mathrm{mg} / \mathrm{m}^{3}$. Analysis of dependencies of "the concentration of phthalate metabolites in the urine - the parameters of pulmonary function" revealed a statistically significant correlation coefficients $(p<0.05)$ of directly proportional dependency of Gensler index (FEVI/SVC) and instantaneous space velocity (MEF 25, 50, 75) on the concentration of monophthalates in urine of the girls. A statistically significant correlation of coefficients $(p<0.05)$ inversely proportional to the forced vital capacity $(F V C)$, forced expiratory volume in the first second (FEVI) and the instantaneous volume velocity after exhaling 50\% (MEF 50) from monophtalates' concentration in the boys' urine.

Key words: phthalates monometylphthalate, monobutylphtalate, monobenzylphtalate, mono-2ethylhexylphthalate, high performance liquid chromatography / mass spectrometry, atmospheric air, lung function parameters.

INTRODUCTION. Phthalates are 1,2benzenedicarboxylic (o-phthalic) acid ethers; synthetic compounds are widely used as plasticizers in the production of polymeric materials for the household, industrial, medical and food purposes. The substances are persistent organic pollutants ubiquitous in the environment [4]. Phthalates are present in a variety of films, shoes and clothing made of artificial leather and synthetic fabrics, construction and finishing materials (washable wallpaper, linoleum, paints, varnishes, etc.), toys, syringes, blood containers, capsules for pharmaceuticals, packaging materials, repellents, cosmetics, perfumes and many other articles [4, 13]. Phthalates are released by the products based on polyvinyl chloride, polystyrene, synthetic and natural rubbers. In the polymeric materials, phthalates are not chemically linked to polymer molecules, and are easily released by heated finished products. One reason for the wide spread of phthalates in the environment is their ability to migrate into the contact medium, eg, air, water, food, which increases with increasing temperature and contact time.

Diethyl phthalate and dibutyl phthalate had the highest concentrations in the indoor air [12]. According to the 1999-2000 research conducted in the US, the metabolites of these phthalates were found in biological media of the adult population [7].

Exposure to phthalates in a domestic environment is expressed in the hormonal and reproductive dysfunctions, genotoxicity, carcinogenesis, and other health disorders [14-17]. Phthalates bear the risk of respiratory diseases in adults and children. Increased incidence of respiratory tract and bronchial obstruction were registered in children living in homes with plastic panels and PVC building materials $[10,12]$. Studies by Hoppin et al found a strong correlation between the increased content of monobutyl phthalate in urine and decreased three indicators of lthe ung function in men - forced vital capacity (FVC), forced expiratory 
volume in the first second (FEV1), and peak volumetric expiratory flow (PEF), contributing to the breathing difficulty [9].

After intake, phthalate transform into monocompound ethers which include alkylated or arylsubstituted ethers of 1,2-benzenedicarboxylic acid (monophthalates). In animal studies, some phthalates and their primary metabolites- monoethers of 1,2-benzenedicarboxylic acid - act as potent reproductive toxicants [8, 11]. Monophthalates are found in urine in the bound and free states. Fixation of monophthalates occurs as a result of conjugation with glucuronic acid to form a glucuronide which enhances the water solubility of the metabolic products and are excreted with urine.

The widespread presence of phthalates in the environment, their role in shaping the risk of some diseases, the need to gather evidence of the associated hazardous effects make quantitative assessment of the health impact of phthalates an important task.

One approach to the assessment of the adverse effects of toxicants is to quantify the exposure of markers - chemical compounds and their metabolites - in human biological samples (blood, urine, exhaled air, etc.), and then to establish their relationship with the body's response $[2,5,6]$.

The paper presents the results of the identification of phthalates in the indoor air of pre-schools and secondary schools, measurements of the concentrations of phthalate metabolites in the child urine, as well as spirometric studies of the pulmonary function in children exposed to phthalates.

METHODOLOGY. To identify the effects of phthalates on the respiratory function in children, biological environments of children were analyzed $(\mathrm{n}=89)$, including 50 boys aged 5-10 and 39 girls aged 5-11 attending pre-school and secondary school.

A biomedical study was carried out in accordance with the ethical principles for biomedical research set out in the Declaration of Helsinki (as amended in 1983), and the Russian national standard GOST R 52379-2005. Written informed consents to voluntary participation in the biomedical research carried out by specialists of the "Federal scientific center for the medical and preventive health risk management technologies" were collected from each child's legal representative included in the sample.

The analysis of four monophthalates in urine - monomethyl ether of 1,2-benzenedicarboxylic acid (mono-Methyl Phthalate MMP), monobutyl ether of 1,2-benzenedicarboxylic acid (mono-Butyl
Phthalate, MBP), mono (2-ethylhexyl) ether of 1,2benzenedicarboxylic acid (mono-Ethylhexyl Phthalate, MEHP) monobenzyl ether and 1,2benzenedicarboxylic acid (mono-Benzil Phthalate, MBzP) - was performed on Agilent 1200 liquid chromatograph (USA) in combination with a quadrupole mass spectrometer detector LC / MS (QQQ) 6460 Agilent Technologies (USA) using electrospray ionization .

Fresh samples were centrifuged, and then enzymatic deglucuronization was performed with $\beta$ glucuronidase to кусушму акуу monophthalates. Extraction of the analyzed phthalates from urine was performed by the method of solid-phase extraction using Oasis HLB cartridges. The extraction rate of MMP equaled $101 \%$, MBP - 96\%, MEHP $102 \%$, and MBzP - 82\%. Quantitative determination was carried out using the method of absolute calibration. The bound of relative error of measurement of monophthalates in urine with the probability $\mathrm{P}=0.95$ (accuracy) did not exceed $25-28 \%$, relative standard deviation of repeatability did not exceed $10-14 \%$, the relative standard deviation of reproducibility did not exceed $9-11 \%$.

Selective determination of MMP, MBP, MBzP, and MEHP in urine was performed on mass-spectrometric detector, using selective reaction monitoring mode (SMR) by receiving specific pairs of parent and daughter ions in the conditions of electrospray ionization in negative polarity mode (Table. 1).

Determination of the levels of 7 phthalates (dimethyl phthalate, diethyl phthalate, dibutyl phthalate, benzylbutyl phthalate, di-(2-ethylhexyl) phthalate, diisodecyl phthalate, didodecyl phthalate) in indoor and outdoor air in pre-schools and secondary schools attended by the surveyed children was conducted by the method of HPLC/MS/MS with electrospray ionization. The samples were collected on glass fiber filters, and sorbent Tenax. To extract phthalates from Tenax and filters, acetonitrile was used. Quantitative determination was carried out by the method of absolute calibration. The range of quantification of phthalates in air totaled $0.0002-0.3 \mathrm{mg} / \mathrm{m} 3$. The bound of relative error of measurement of monophthalates in urine with the probability $\mathrm{P}=0.95$ accuracy) did not exceed $15-30 \%$, relative standard deviation of repeatability did not exceed $5-14 \%$, relative standard deviation of reproducibility did not exceed 6-15\%.

Selective determination of phthalates was performed by the method of HPLC/MS/MS on liquid chromatograph Agilent 1200 with quadrupole 
Assessment of the airborne phthalate exposure on lung function of preschool and primary school children ...

mass spectrometer detector LC/MS while using ions in the selective monitor response mode electrospray under positive polarity by obtaining (SMR) (see Table. 2).

specific pairs of parental and supporting daughter

Table 1

Characteristic of ions for qualitative and quantitative determination of monophthalates in urine on mass spectrometric detector LC/MS (QQQ)

\begin{tabular}{|c|l|c|c|c|}
\hline № & Substance & Mol.weight & Parent ion, $\mathrm{m} / \mathrm{z}$ & $\begin{array}{c}\text { Daughter ion, } \\
\mathrm{m} / \mathrm{z}\end{array}$ \\
\hline 1 & mono-Methyl Phthalate & 180,16 & 179 & 77 \\
\hline 2 & mono-Butyl Phthalate & 222,24 & 221 & 77 \\
\hline 3 & mono-Benzil Phthalate & 256,25 & 255 & 77 \\
\hline 4 & mono-2-Ethylhexyl Phthalate & 278,34 & 277 & 134 \\
\hline
\end{tabular}

Table 2

Characteristic of ions for qualitative and quantitative determination of phthalates in air using mass spectrometric detector LC/MS (QQQ)

\begin{tabular}{|c|l|c|c|c|}
\hline № & \multicolumn{1}{|c|}{ Substance } & Mol.weight & Parent ion, $\mathrm{m} / \mathrm{z}$ & $\begin{array}{c}\text { Daughter ion, } \\
\mathrm{m} / \mathrm{z}\end{array}$ \\
\hline 1 & Dimethyl Phthalate & 194,2 & 195,1 & 163,1 \\
\hline 2 & Diethyl Phthalate & 222,2 & 223,1 & 149 \\
\hline 3 & Dibutyl Phthalate & 278,4 & 279,2 & 91 \\
\hline 4 & BenzylButyl Phthalate & 312,4 & 313,2 & 149 \\
\hline 5 & Di-(2-ethylhexyl) phthalate & 390,6 & 391,3 & 149 \\
\hline 6 & Diisodecyl phthalate & 447 & 447,4 & 149 \\
\hline 7 & Didodecyl phthalate & 502,8 & 503,4 & 149 \\
\hline
\end{tabular}

Spirometry was performed by the Department of Functional Diagnostics of the Federal Scientific Center for the Medical and Preventive Health Risk Management Technologies using spirometric computer system MasterScreen IOS by Erich Jaeger (CareFusion, Germany). In the calculations, the proper values by Jaeger standart proposed by the developer were used. The measurements of the lung function was performed by the following parameters: forced vital capacity (FVC), slow vital capacity (SVC), forced expiratory volume in the first second (FEV1), Gensler index (FEV1 / SVC), peak expiratory flow (PEF), instantaneous space velocity after exhaling $25 \%$ of forced vital capacity (MEF 25), instantaneous volume velocity after exhaling $50 \%$ of forced vital capacity (MEF 50), instantaneous volume velocity after exhaling $75 \%$ of forced vital capacity (MEF $75)$.
The relation between the monophthalate content in urine and the lung function parameters in children was examined with the help of linear regression analysis. The quality of the model was estimated using the determination coefficient $\left(R^{2}\right)$. This coefficient describes the ratio of the explained variance by the variables included in the model. The significance of the relations was evaluated using Student's test [16].

RESULTS AND DISCUSSION. Table 3 below shows the results of the analysis of the lung function parameters $(\mathrm{M} \pm \mathrm{m})$ and standard values on a group average (girls, boys). Overall, the groups show a higher MEF 25 and MEF 50 indicators, and a positive FEV1 for girls; and lower FVC, PEF, MEF 25 and MEF 50 for boys as compared to the standard values. 
Table 3

The Results of a Spirographic Study in Children ( $\mathrm{n}=89), 2015$

\begin{tabular}{|c|c|c|c|c|}
\hline \multirow{2}{*}{ Indicator, units } & \multicolumn{2}{|c|}{ Girls $(n=39)$} & \multicolumn{2}{|c|}{ Boys $(n=50)$} \\
\hline & Norm & $\mathrm{M} \pm \mathrm{m}$ & Norm & $\mathrm{M} \pm \mathrm{m}$ \\
\hline Forced vital capacity (FVC), $\mathrm{dm}^{3}$ & 1,79 & $\begin{array}{c}1,77 \pm \\
0,16\end{array}$ & 2,07 & $\begin{array}{c}1,908 \pm \\
0,149\end{array}$ \\
\hline $\begin{array}{l}\text { forced expiratory volume in the first second (FEV1), } \\
\mathrm{dm}^{3}\end{array}$ & 1,85 & $\begin{array}{c}1,61 \pm \\
0,14\end{array}$ & 1,94 & $\begin{array}{c}1,88 \pm \\
0,32\end{array}$ \\
\hline FEV1/SVC ratio, $\%$ & 90,41 & $\begin{array}{c}90,30 \pm \\
2,50\end{array}$ & 89,8 & $\begin{array}{c}90,26 \pm \\
1,91\end{array}$ \\
\hline peak expiratory flow (PEF), $\mathrm{dm}^{3} / \mathrm{s}$ & 3,50 & $\begin{array}{c}3,46 \pm \\
0,42\end{array}$ & 3,74 & $\begin{array}{c}3,46 \pm \\
0,28\end{array}$ \\
\hline $\begin{array}{l}\text { Instantaneous space velocity after exhaling } 25 \% \text { of } \\
\text { forced vital capacity (MEF } 25), \mathrm{dm}^{3} / \mathrm{s}\end{array}$ & 1,22 & $\begin{array}{c}1,29 \pm \\
0,17\end{array}$ & 1,27 & $\begin{array}{c}1,24 \pm \\
0,14\end{array}$ \\
\hline $\begin{array}{l}\text { instantaneous volume velocity after exhaling } 50 \% \text { of } \\
\text { forced vital capacity (MEF 50), } \mathrm{dm}^{3} / 3\end{array}$ & 2,30 & $\begin{array}{c}2,34 \pm \\
0,23\end{array}$ & 2,41 & $\begin{array}{c}2,34 \pm \\
0,19\end{array}$ \\
\hline $\begin{array}{l}\text { instantaneous volume velocity after exhaling } 75 \% \text { of } \\
\text { forced vital capacity (MEF } 75), \mathrm{dm}^{3} / \mathrm{s}\end{array}$ & - & $\begin{array}{c}3,11 \pm \\
0,28\end{array}$ & - & $\begin{array}{c}3,27 \pm \\
0,25\end{array}$ \\
\hline Slow vital capacity $(\mathrm{SVC}), \mathrm{dm}^{3}$ & - & $\begin{array}{c}1,83 \pm \\
0,57\end{array}$ & - & $\begin{array}{c}1,91 \pm \\
0,20\end{array}$ \\
\hline
\end{tabular}

Table 4 below shows the results of the analy- in 18\%, and mono-Ethylhexyl Phthalate - in singusis of phthalate metabolites in child urine $(\mathrm{M} \pm \mathrm{m})$. lar cases $(4.9 \%)$ in the concentration range of The presence of mono-Methyl Phthalate was regis- $0,00039-0,012 \mathrm{mg} / \mathrm{dm}^{3}, 0,00072-0,0104 \mathrm{mg} / \mathrm{dm}^{3}$ tered in $33 \%$ of children, mono-Butyl Phthalate - and $0,0007-0,0009 \mathrm{mg} / \mathrm{dm}^{3}$ respectively.

Table 4

The Results of the Analysis of Monoethers of 1.2-1,2-Benzenedicarboxylic Acid in Child Urine Conducted by the Method of HPLC/MS/MS (n=89), 2015

\begin{tabular}{|l|c|c|c|c|}
\hline \multirow{2}{*}{ Identified Compound } & \multicolumn{4}{|c|}{ Monophthalate concentration in urine, $\mathrm{mg} / \mathrm{dm}^{3}$} \\
\cline { 2 - 5 } & \multicolumn{2}{|c|}{ Girls $(\mathrm{n}=39)$} & \multicolumn{2}{c|}{ Boys $(\mathrm{n}=50)$} \\
\hline & Norm & $\mathrm{M} \pm \mathrm{m}$ & Norm & $\mathrm{M} \pm \mathrm{m}$ \\
\hline MMP & 0 & $0,0015 \pm 0,0009$ & 0 & $0,0014 \pm 0,0007$ \\
\hline MBP & 0 & $0,00074 \pm 0,0003$ & 0 & $0,00106 \pm 0,0006$ \\
\hline MBzP & 0 & 0 & 0 & 0 \\
\hline MEHP & 0 & $0,00002 \pm 0,00001$ & 0 & $0,00006 \pm 0,00003$ \\
\hline Total monophthalates & 0 & $0,00206 \pm 0,00038$ & 0 & $0,00252 \pm 0,00032$ \\
\hline
\end{tabular}

Analysis of the phthalate concentrations in the indoor air of pre-schools $(n=35)$ showed the presence of diethyl phthalate in $17 \%$ of samples with the concentration range of $0,00028-0,00061$ $\mathrm{mg} / \mathrm{m}^{3}$, dibutylphthalate $-42 \%$ of samples with the concentration of $0,00052-0,00116 \mathrm{mg} / \mathrm{m}^{3}$, di(2-ethylhexyl)phthalate - in $31 \%$ of samples with the concentration range of 0,00023-0,0035 $\mathrm{mg} / \mathrm{m}^{3}$, and diisodecylphthalate - in $11 \%$ of samples with the concentration of $0,0002 \mathrm{mg} / \mathrm{m}^{3}$, which is below the current hygienic standards on the phthalate concentrations in air (SRLI 0,1$0,01 \mathrm{mg} / \mathrm{m}^{3}$, MPC d. av. $\left.0,007 \mathrm{mg} / \mathrm{m}^{3}\right)$. In the outdoor air at the pre-schools $(n=6)$, diethylphthalate $\left(0,00028 \mathrm{mg} / \mathrm{m}^{3}\right)$ and $\mathrm{di}-(2-$ ethylhexyl)phthalate $\left(0,0021 \mathrm{mg} / \mathrm{m}^{3}\right)$ were registered in singular cases. The maximal level of in- 
door and outdoor air pollution was registered with dibutylphthalate and di-(2-ethylhexyl)phthalate.

In the indoor air of schools $(n=15)$, the presence of the following compounds was registered: diethylphthalate - in $53 \%$ of samples with the concentration of $0,00021-0,00054 \mathrm{mg} / \mathrm{m}^{3}$, dibutylphthalate - in $46 \%$ of samples with the concentration of $0,00026-0,00075 \mathrm{mg} / \mathrm{m}^{3}$, $\mathrm{di}-(2-$ ethylhexyl)phthalate - in $6 \%$ of samples with the concentration of $0,00026 \mathrm{mg} / \mathrm{m}^{3}$, and diisodecylphthalate - in $26 \%$ of samples with the concentration of $0,00024-0,00025 \mathrm{mg} / \mathrm{m}^{3}$. In the outdoor air at schools $(n=6)$, the following compounds were registered in singular cases: dibutylphthalate $\left(0,00042-0,00078 \quad \mathrm{mg} / \mathrm{m}^{3}\right)$ and diisodecylphthalate $\left(0,00024 \mathrm{mg} / \mathrm{m}^{3}\right)$ below the hygienic standards. The biggest indoor air pollutants were diethylphthalate and dibutylphthalate, and outdoor air pollutants - dibutylphthalate.
The presence of phthalates in the indoor and outdoor air indicates their chronic impact on public health via the inhaled air.

The results of the calculations yielded the approximation data on the 'monophthalate (total monophthalates) - lung function parameter' correlation for boys and girls aged 6, 7, 8, and 9 (if a sample was small, the children of two age groups were combined into one group), as well as aged 511 for girls and 5-10 for boys. Statistically significant correlation coefficients $(p<0.05)$ were established of directly proportional dependencies of Hensler Index (FEV1/SVC) and instantaneous volume velocity (MEF 25, 50, 75) and monophthalate concentrations in urine for girls (Table 5, Figures 1, 2).

Statistically significant correlation coefficients were determined in boys $(p<0,05)$ of inverse relationships between FVC, FEV1, MEF50, and monophthalate concentration in urine (Table 6, Figure 3, 4).

Table 5

Statistically significant dependences between the lung function parameters and monophthalate content in urine in girls $(\mathrm{n}=39), 2015$

\begin{tabular}{|l|c|l|c|c|}
\hline \multicolumn{1}{|c|}{ Dependency } & Group & \multicolumn{1}{c|}{$\mathrm{y}=\mathrm{ax}+\mathrm{b}$} & $R^{2}$ & $p$ \\
\hline MMP / Hensler Index & 6-11 y.o. & $\mathrm{y}=1060,9 \mathrm{x}+88,7$ & 0,5525 & $<0,05$ \\
\hline MMP / MEF50 & 5-11 y.o. & $\mathrm{y}=85,658 \mathrm{x}+2,1$ & 0,2952 & $<0,05$ \\
\hline MBP / MEF50 & 7-10 y.o. & $\mathrm{y}=165,76 \mathrm{x}+1,8$ & 0,7216 & $<0,05$ \\
\hline Total MP / Hensler Index & 5-11 у.o. & $\mathrm{y}=1174,4 \mathrm{x}+85,3$ & 0,4898 & $<0,05$ \\
\hline Total MP / MEF25 & 5-11 у.o. & $\mathrm{y}=98,274 \mathrm{x}+0,8$ & 0,6311 & $<0,05$ \\
\hline Total MP / MEF50 & 5-11 лет & $\mathrm{y}=58,766 \mathrm{x}+1,8$ & 0,1635 & $<0,05$ \\
\hline Total MP / MEF75 & 5-11 лет & $\mathrm{y}=85,35 \mathrm{x}+2,8$ & 0,1608 & $<0,05$ \\
\hline
\end{tabular}

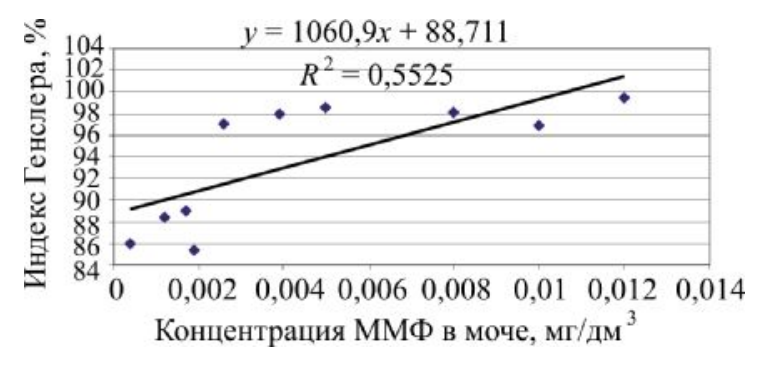

Figure 1. Approximation of the dependence betwee mono-M ethyl Phthalate in urine of girls and Hensle Index (6-11 y.0.)

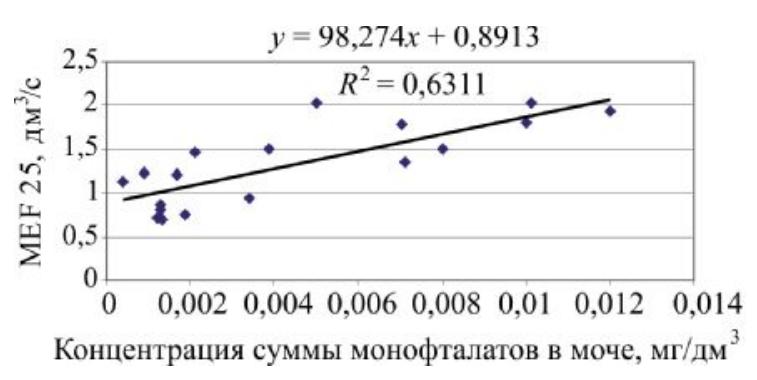

емкости легких (MEF25)» (группа 5-11 лет) Figure 2. Approximation of the dependence between total phthalates in urine of girls and MEF25

(5-11 y.o.) 
M ono-M ethyl Phthalate content in urine, $\mathrm{mg} / \mathrm{dm} 3$

Table 6

Statistically significant dependences between the lung functionparameters and monophthalate content in urine in boys $(n=50), 2015$

\begin{tabular}{|l|c|c|c|c|}
\hline \multicolumn{1}{|c|}{ Dependency } & Group & $\mathrm{y}=\mathrm{ax}+\mathrm{b}$ & $R^{2}$ & $p$ \\
\hline MMP / FVC & 7 y.o. & $\mathrm{y}=-78,924 \mathrm{x}+1,8669$ & 0,9341 & $<0,05$ \\
\hline MMP / FEV1 & 7 y.o. & $\mathrm{y}=-81,267 \mathrm{x}+1,7486$ & 0,8279 & $<0,05$ \\
\hline MBP / FEV1 & 9 y.o. & $\mathrm{y}=-1594 \mathrm{x}+4,4341$ & 0,9852 & $<0,05$ \\
\hline Total MP / Hensler Index & 5-10 y.o. & $\mathrm{y}=872,88 \mathrm{x}+87,021$ & 0,1363 & $<0,05$ \\
\hline MMФ / MEF50 & 5-6 y.o. & $\mathrm{y}=-121,16 \mathrm{x}+2,3149$ & 0,6043 & $<0,05$ \\
\hline
\end{tabular}

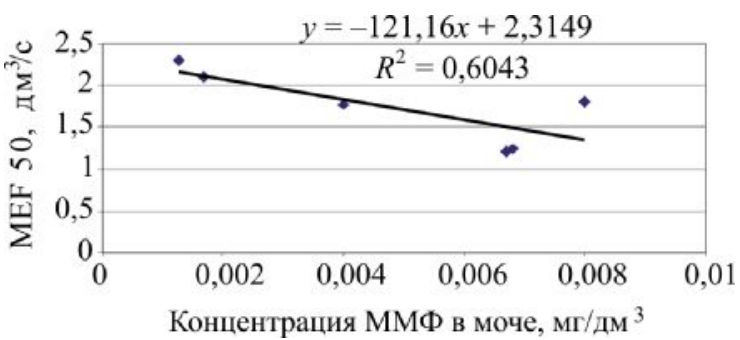

Figure 3. Approximation of the dependence between total phthalates in urine of girls and M EF50 (5-6 y.0.)

\section{MP concentration in irine, $\mathrm{mg} / \mathrm{dm} 3$}

Overall, the analysis revealed depression of the lung function due to elevated levels of monophthalates in urine of boys as opposed to girls which showed mainly positive statistically significant regression coefficients $(0,1608-0,7216)$.

\section{CONCLUSIONS}

1. In $11-42 \%$ of the indoor air samples (preschools), the presence of 4 (diethylphthalate, dibutylphthalate, di-(2-ethylhexyl)phthalate, and diisodecylphthalate) out of 7 analyzed phthalates was registered. The concentrations were registered at $0,0002-0,0035 \mathrm{mg}-\mathrm{m} 3$ which was below the hygienic standards.

Outdoor air samples (preschools) revealed in singular cases the presence of diethylphthalate

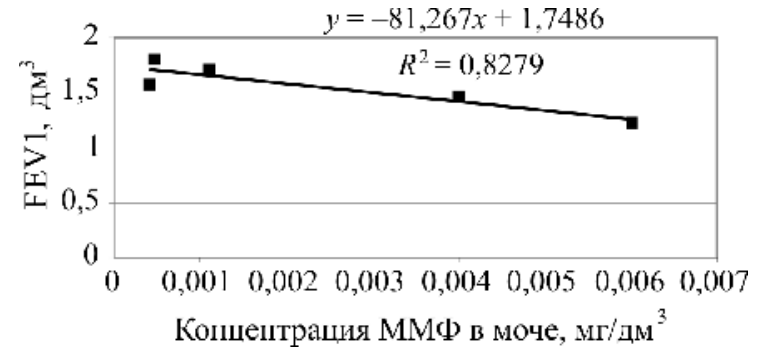

Figure 4. Approximation of the dependence between total phthalates in urine of girls and FEV 1

(7 y.0.)

and di-(2-ethylhexyl)phthalate at 0,00028-0,0021 $\mathrm{mg} / \mathrm{m} 3$ which was also below the hygienic standard.

2. In 6-53\% of the indoor air samples (secondary schools), the presence of 4 (diethylphthalate, dibutylphthalate, di-(2ethylhexyl)phthalate, and diisodecylphthalate) out of 7 analyzed phthalates was registered at the concentration of $0,00021-0,00075 \mathrm{mg} / \mathrm{m} 3$.

Outdoor air samples (secondary schools) revealed the presence of dibutylphthalate and diisodecylphthalate at the concentration of $0,00024-0,00078 \mathrm{mg} / \mathrm{m} 3$ which was also below the hygienic standards. 
Assessment of the airborne phthalate exposure on lung function of preschool and primary school children ...

The biggest indoor air pollutants (preschools and secondary schools) included dibytylphthalate, di-(2-ethylhexyl)phthalate, and diethylphthalate. Indoor and outdoor air at secondary schools had a higher level of pollutants.

4. Analysis of the child urine revealed the presence of monomethylphthalate in $33 \%$ of the samples monobutylphthalate - in $18 \%$, and monoethylhexylphthalate in singular cases $(4.9 \%)$ at 0,00039-0,012 $\mathrm{mg} / \mathrm{dm}^{3}, 0,00072-0,0104 \mathrm{mg} / \mathrm{dm}^{3}$ and $0,0007-0,0009 \mathrm{mg} / \mathrm{dm}^{3}$ respectively.

5. Hensler Index (FEV1/SVC) and instantaneous volume velocity (MEF25, 50, and 75) were proved to be significantly related to the increased concentrations of monomethylphthalate, monobutylphthalate and total monophthalates in urine of girls $\left(R^{2}=0,55 ; \mathrm{p}<0,05\right)$.
6. Forced vital capacity (FVC), forced expiratory volume in the first second (FEV1) and instantaneous volume velocity (MEF 50) were proved to be significantly related to decreased concentrations of monomethylphthalate and monobutylphthalate in the urine of boys $\left(\mathrm{R}^{2}=0,6 \div\right.$ $0,8 ; \mathrm{p}<0,05)$.

7. The presence of phthalates in the indoor and outdoor air indicates their possible chronic impact on child health through exhaled air. The obtained statistically significant dependences between the concentration of phthalate metabolites in urine and biological response (lung function parameters) could serves as evidence of the negative health effects associated with chronic phthalate inhalation exposure of children.

\section{References}

1. Glanc S. Mediko-biologicheskaja statistika [Biomedical Statistics]. Moscow: Praktika, 1999, 459 p. (in Russian).

2. May I.V., Khoroshavin V.A., Evdoshenko V.S. Algoritm i metody sanitarno-jepidemiologicheskogo rassledovanija narushenij prav grazhdan na blagoprijatnuju okruzhajushhuju sredu obitanija s jetapom ocenki riska dlja zdorov'ja [Algorithms and methods of sanitary-epidemiological investigation of civil rights violations on a favorable habitats with step of health risk assessment]. Zdorov'e naselenija i sreda obitanija, 2010, no. 11, pp. 28-30. (in Russian).

3. Majstrenko V.N., Kljuev N.A. Jekologo-analiticheskij monitoring stojkih organicheskih zagrjaznitelej [Ecological and analytical monitoring of persistent organic pollutants]. BINOM, Laboratorija znanij, Moscow, 2004, 328 p. (in Russian).

4. Zaitseva N.V., Ulanova T.S.. Nurislamova T.V., Karnazhickaya T.D., Plahova L.V., Suetina G.N. Metodicheskie podhody i kriterii ocenki pri opredelenii himicheskih soedinenij v biosredah [Methodical approaches and criteria in determining the chemical compounds in biological milieus]. Materialy Plenuma Laboratornogo Soveta gosudarstvennoj sanitarno-jepidemiologicheskoj sluzhby Rossijskoj Federacii, Moscow, 2004, pp. 59-64. (in Russian).

5. Onishhenko G.G., Zaitseva N.V., Ulanova T.S. Kontrol' soderzhanija himicheskih soedinenij i jelementov $\mathrm{v}$ biologicheskih sredah [Control of chemical elements and compounds in biological milieus]. Perm': Izd-vo «nizhnyj format», 2011, 520 p. (in Russian).

6. Ulanova T.S. Sistema himiko-analiticheskoj podderzhki sanitarno-gigienicheskih issledovanij (medikobiologicheskie aspekty) [The system of chemical-analytical support of sanitary research (medical and biological aspects)]. Gigienicheskie i mediko-profilakticheskie tehnologii upravlenija riskami zdorov'ju naselenija $v$ promyshlenno razvityh regionah: materialy nauch.-prakt. konf. s mezhdunar. Uchast. Perm', 2010, pp. 62-67. (in Russian).

7. Gray L.E., Jr, Wolf C., Lambright C., Mann P., Price M., Cooper R.L., Ostby J. Administration of potentially antiandrogenic pesticides (procymidone, linuron, iprodione, chlozolinate, p,p'-DDE, and ketoconazole) and toxic substances (dibutyl and diethylhexyl phthalate, PCB 169, and ethane dimethane sulphonate) during sexual differentiation produces diverse profiles of reproductive malformations in the male rat. Toxicol Ind Health, 1999, no. 15 (1-2), pp. 94-118.

8. Blount B., Silva M., Caudill S., Needham L., Pirkle J., Sampson E., Lucier G., Jackson R., Brock J. Levels of seven urinary phthalate metabolites in a human reference population. Environ. Health. Perspect, 2000, no. 108 (10), pp. 979-982.

9. Hoppin, J.A, Ulmer, R. \& London, S.J. (2004) Phthalate Exposure and Pulmonary Function. Environmental Health Perspectives, 2004, no. 112 (5), pp. 571-574

10. Jaakkola J.J., Verkasalo P.K., Jaakkola N. Plastic Wall Materials in the Home and Respiratory Health in Young Children. Am. Journal of Public Health, 2000, Vol. 90, no. 5, pp. 797- 799.

11. Mylchreest E, Cattley RC, Foster PM. Male reproductive tract malformations in rats following gestational and lactational exposure to Di (n-butyl) phthalate: an antiandrogenic mechanism?. Toxicol Sci, 1998, no. 43, pp. 47-60. 
12. Rudel R., Camann D., Spengler J., Korn L., Brody J. Phthalates, Alkylphenols, pesticides, polybrominated diphenyl ethers, and other endocrine-disrupting compounds in indoor air and dust. Environmental Science and Technology, 2003, no. 37 (20), pp. 4543-4553.

13. Substance Monograph: Di (2-ethylhexyl) phthalate (DEHP). Opinion of the Human Biomonitoring Commission of the German Federal Environmental Agency, Published in: Bundesgesundheitsblatt - Gesundheitsforschung - Gesundheitsschutz, 2005, no. 48 (6), pp. 706-722.

14. Ponsonby A.L., Dwyer T., Kemp A., Cochrane J., Couper D., Carmichael A. Synthetic Bedding and Wheeze in Childhood. Epidemiology, 2003, no. 14, pp. 37-44.

15. Toxicological Profile for Di (2-ethylhexyl) Phthalate. U.S. Department of Health and Human Services, Public Health Service, Agency for Toxic Substances and Disease Registry, 1993, 291 p.

16. Toxicological Profile for DiethylPhthalate. U.S. Department of Health and Human Services, Public Health Service, Agency for Toxic Substances and Disease Registry, 1993, 125 p.

17. Toxicological Profile for Di-n-butylPhthalate. U.S. Department of Health and Human Services, Public Health Service, Agency for Toxic Substances and Disease Registry, 1990, 184 p. 